\title{
THE EFFECT OF INTERACTION OF SYSTEMATIC FACTORS ON MILK PERFORMANCE OF SIMMENTAL COWS IN STANDARD LACTATION
}

\author{
M.D. Petrović ${ }^{*}$, M.M. Petrović ${ }^{2}$, Z. Skalicki ${ }^{3}$, V. Bogdanović ${ }^{3}$, R. Đoković ${ }^{1}$, S. \\ Rakonjac $^{1}$ \\ ${ }^{1}$ Faculty of Agronomy, Cacak \\ ${ }^{2}$ Institute for Animal Husbandry, Belgrade-Zemun \\ ${ }^{3}$ Faculty of Agriculture, Belgrade-Zemun \\ *Corresponding author: Milun D. Petrovic, e-mail: milunp@tfc.kg.ac.rs \\ Original scientific paper
}

\begin{abstract}
The effect of interaction between the farm and calving season, as well as the farm and group of lactations on milk performance traits (milk yield, yield of milk fat, 4\% fat corrected milk and milk fat content) was analyzed on sample of 2805 Simmental cows with total 9718 standard lactations, housed on dairy farm "Zlatiborski suvati" on Zlatibor (578 cows and 1968 lactations), dairy farm of the Agricultural holding Dobričevo in Ćuprija (964 cows and 3237 lactations) and dairy animals housed on family farms/households in the region of Kotraža (1263 cows and 4513 lactations). The significance of the effect of interaction between the farm and calving season, as well as interaction between the farm and group of lactations on all milk performance traits was very high $(\mathrm{P}<0.001)$, which justified their inclusion into models for assessment of the breeding value of dairy cows. The share of variance of interactions in total variance of milk performance traits in standard lactations was low (below and around 4\%), which clearly indicated even more systematic factors and their interactions which influence the total variability of observed traits of milk performance of cows in standard lactations.
\end{abstract}

Key words: systematic factors, interaction, lactation, Simmental breed.

\section{Introduction}

The cattle breeding procedures used today most commonly employ linear methods and models that combine fixed parameters (year, farm, season, lactation) and random variables (age at first conception or calving, genetic effect of sire, genetic effect of an individual animal, etc.) which can be mutually dependent (related) or independent, with or without interactions, depending on the trait analysed. The selected model results essentially in the breeding value of an individual animal (Bogdanović et al., 2003). 
Depending on the level of production, sample size and mathematical statistical model, non-genetic discontinuous factors (year, farm, season, lactation) can account for as much as above $50 \%$ of the total variations in milk production (Stojic et al., 1996). The same authors, Stojić et al., 1995, reported that farm, year and season of calving induced $35.7 \%$ of total variations in milk production. A somewhat lower percentage of non-genetic factors (farm, year, calving season and lactation number) of $22.7 \%$ in the total variability of performance traits was found by Jovanovac (1987), whereas Hansen et al., 1983 reported a considerably higher percentage of about $45 \%$ (in terms of the farm-year-season effect).

The effect of season of birth of cows and their calving, i.e. beginning of lactation as systematic factor, on traits of milk performance is reflected through various climatic circumstances and nutrition throughout the year, so it is included into models for evaluation of breeding value of dairy animals.

Moat of domestic and foreign authors indicate significant and highly significant effect of order of lactation, i.e. groups of lactations on expression of production traits. Namely, maximum production of milk is achieved depending on the intensity of breeding in the period from the third until the fifth lactation. The lowest production of milk is in the first lactation, due to insufficient body development of animals, whereas drop in production occurring after the third i.e. fifth lactation often occurs due to health disorders.

Breeding region or farm usually have significant impact on milk performance traits due to different rearing methods, nutrition, housing, care, climatic conditions, age structure and herd size, as well as series of other influences related to work and farm management.

\section{Material and methods}

The effect of systematic, non-genetic factors and their interactions on traits of milk performance in standard lactations was analyzed on sample of 2805 Simmental cows with total 9718 standard lactations, housed on dairy farm "Zlatiborski suvati" on Zlatibor, dairy farm of the Agricultural holding Dobričevo in Ćuprija and dairy animals housed on family farms/households in the region of Kotraža.

Distribution of standard lactations according to classes of systematic influences is presented in Table 1 . 
Table 1. Presentation of data across different classes of major systematic effects

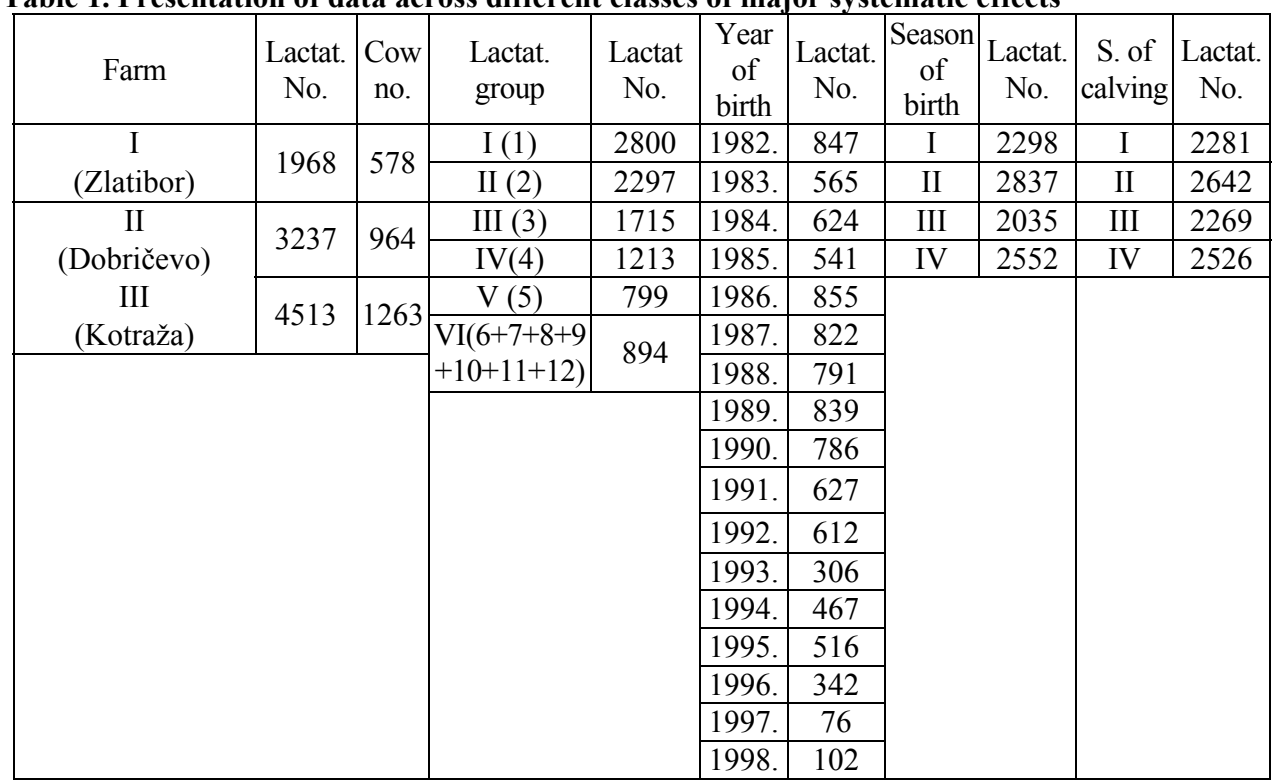

The impact of following systematic factors on expression of production traits in standard lactations, such as milk yield in standard lactation (MYSL, kg), milk fat content in standard lactations (MFCSL, \%), milk fat yield in standard lactations (MFYSL, $\mathrm{kg}$ ) and yield of $4 \%$ fat corrected milk in standard lactations (4\%FCMSL, $\mathrm{kg}$ ), was observed:

- Breeding area. The effect of three farm locations was studied (the farm on Mt. Zlatibor, Dobričevo farm and farms in the Kotraža region).

- Lactation groups. Lactation groups were established in order to equalise the number of animals within different lactations as much as possible and reduce variability:

- Group I (first lactation),

- Group II (second lactation),

- Group III (third lactation),

- Group IV (fourth lactation),

- Group V (fifth lactation),

- Group VI (sixth and other lactations),

- Calving season, i.e. the onset of lactation (I-spring season (March through May), IIsummer season (June through August), III-autumn season (September through November), IV-winter season (December through February)).

- Year of birth $x$ season of birth interaction (cows that calved from 1982 to $1998 \times 4$ seasons (I-spring, II-summer, III-autumn and IV-winter seasons)). 
- Breeding area $x$ calving season interaction (3 breeding areas $\mathrm{x} 4$ calving seasons).

- Breeding area x lactation group interaction (3 breeding areas x 6 lactation groups).

- Age at first conception.

For analysis of the mentioned non-genetic factors and their interactions on production traits in standard lactations, a general linear model was used based on application of the method of least squares of the statistical software Statistica for Windows Release 6.0, which in this case is:

$$
\mathbf{y}_{\mathrm{ijkl}}=\mu+\mathbf{B}_{\mathrm{i}}+\mathbf{L}_{\mathrm{j}}+\mathbf{G}_{\mathrm{k}}+\mathbf{C} \mathbf{s}_{1}+\mathbf{B C} \mathbf{s}_{\mathrm{il}}+\mathbf{B} \mathbf{L}_{\mathrm{ij}}+\mathbf{b}_{1}\left(\mathbf{x}_{1}-\bar{x}_{1}\right)+\mathbf{e}_{\mathrm{ijkl}} \text {, where: }
$$

$\mathbf{y}_{\mathrm{ijkl}}$ - an individual animal of the i-th breeding area, $\mathrm{j}$-th lactation group, k-th group, 1-th calving season,

$\boldsymbol{\mu}$ - population mean with equal participation of all classes of effects (B, L, G, Cs, $\mathrm{BCs}, \mathrm{BL}$ ),

$\mathbf{B}_{i}$ - fixed effect of the i-th breeding area (1-3),

$\mathbf{L}_{j}$ - fixed effect of the $j$-th lactation group (1-6),

$\mathbf{G}_{\mathrm{k}}$ - fixed effect of the k-th group (year of birth x season of birth) (1-68),

$\mathbf{C s}_{1}$ - fixed effect of the 1-th calving season (1-4),

$\mathbf{B C s}_{\mathbf{i l}}$ - fixed effect of the i-th breeding area x 1-th calving season interaction (1-12),

$\mathbf{B L}_{\mathrm{ij}}$ - fixed effect of the $\mathrm{i}$-th breeding area $\mathrm{x} j$-th lactation group interaction (1-18),

$\mathbf{b}_{1}$ - linear regression coefficient of the effect of age at first conception, and $\mathbf{e}_{\mathrm{ijkl}}-$ other undetermined effects.

\section{Results and discussion}

In research results only the results of the effect of interaction between systematic factors on expression of milk performance traits in standard lactations according to applied model are presented.

Mean values of least squares, standard errors and significance of the influence of interaction farm and calving season on production traits of standard lactations according to applied model are presented in Table 2. 
Table 2. Mean values of least squares, standard errors and significance of the influence of interaction farm and calving season on production traits of standard lactations

\begin{tabular}{|c|c|c|c|c|c|c|c|c|c|c|}
\hline \multicolumn{3}{|c|}{ Systematic factors } & \multicolumn{2}{|c|}{$\begin{array}{c}\text { MYSL } \\
(\mathrm{kg})\end{array}$} & \multicolumn{2}{|c|}{$\begin{array}{c}\text { MFCSL } \\
(\%)\end{array}$} & \multicolumn{2}{|c|}{$\begin{array}{c}\text { MFYSL } \\
(\mathrm{kg})\end{array}$} & \multicolumn{2}{|c|}{$\begin{array}{c}\text { 4\%FCMSL } \\
(\mathrm{kg})\end{array}$} \\
\hline Farm & $\begin{array}{c}\text { Calving } \\
\text { season }\end{array}$ & $\mathrm{N}$ & LSM & $\mathrm{SE}_{\mathrm{LSM}}$ & LSM & $\mathrm{SE}_{\mathrm{LSM}}$ & LSM & $\mathrm{SE}_{\mathrm{LSM}}$ & LSM & $\mathrm{SE}_{\mathrm{LSM}}$ \\
\hline I & I & 374 & 4460,4 & 41,734 & 3,66 & 0,008 & 162,79 & 1,582 & 4226,0 & 40,220 \\
\hline I & II & 425 & 4245,2 & 39,206 & 3,67 & 0,007 & 155,21 & 1,486 & 4026,2 & 37,783 \\
\hline I & III & 593 & 4320,1 & 33,228 & 3,68 & 0,006 & 158,64 & 1,260 & 4107,6 & 32,022 \\
\hline I & IV & 576 & 4394,5 & 33,430 & 3,67 & 0,006 & 160,76 & 1,267 & 4169,2 & 32,217 \\
\hline II & I & 705 & 4007,8 & 31,350 & 3,79 & 0,006 & 151,64 & 1,188 & 3877,7 & 30,212 \\
\hline II & II & 771 & 3860,7 & 30,003 & 3,77 & 0,005 & 145,50 & 1,137 & 3726,8 & 28,914 \\
\hline II & III & 908 & 4168,7 & 28,327 & 3,78 & 0,005 & 157,60 & 1,074 & 4031,5 & 27,299 \\
\hline II & IV & 853 & 4182,3 & 29,103 & 3,80 & 0,005 & 158,85 & 1,103 & 4055,7 & 28,047 \\
\hline III & I & 1202 & 3962,4 & 24,988 & 3,91 & 0,005 & 154,89 & 0,947 & 3908,4 & 24,081 \\
\hline III & II & 1446 & 3925,9 & 22,548 & 3,91 & 0,004 & 153,60 & 0,855 & 3874,4 & 21,729 \\
\hline III & III & 768 & 3962,3 & 29,093 & 3,91 & 0,005 & 155,02 & 1,103 & 3910,2 & 28,037 \\
\hline III & IV & 1097 & 4005,9 & 25,476 & 3,91 & 0,005 & 156,61 & 0,966 & 3951,5 & 24,551 \\
\hline \multicolumn{3}{|c|}{$\mathrm{F}_{\mathrm{exp}}$} & \multicolumn{2}{|c|}{$9.39^{* * *}$} & \multicolumn{2}{|c|}{$4.60^{* * *}$} & \multicolumn{2}{|c|}{$9.82^{* * * *}$} & \multicolumn{2}{|c|}{$9.71^{* * *}$} \\
\hline
\end{tabular}

The effect of interaction between the farm and calving season on all milk traits of standard lactations was highly significant $(\mathrm{P}<0.001)$, therefore, inclusion not only of these individual systematic factors but also their interactions into models for evaluation of breeding value of cows is justified. The effect farmsyear-season, according to research by Stojić (1996), was the most dominant effect for all studied milk performance indicators in standard lactation $(\mathrm{P}<0.01)$. Petrović M.M. et al., 1997 and Petrović D.M. et al. 2009, in their study of the active population of Simmental cattle in Serbia, indicated that interaction between breeding region and calving season contributed to significant variation in the milk yield and yield of milk fat $(\mathrm{P}<0.01)$. Very significant $(\mathrm{P}<0.01)$ and significant $(\mathrm{P}<0.05)$ effect of breeding region, as individual systematic factor, on production traits of Simmental cows is indicated by Petrović et al., 1997 and 2006, Perišić, 1998, Rychen, 1999, Chladek and Kucera, 2000, Đurđević, 2001, Đurđević et al., 2002, Panić, 2005 and Petrović D.M. et al., 2009.

Share of interaction between farm and calving season in total variance of milk traits in standard lactations was very low and ranged from only $0.18 \%$ in case of milk fat yield to $0.49 \%$ in case of production of $4 \%$ fat corrected milk, which clearly indicated the high contribution of other systematic factors in variability of these traits which are included into presented model and were not considered in this study. Low level of share of variance of certain systematic factors in total variability of production of $4 \%$ fat corrected milk is stated in the research of Petrovic D.M. et al., 2010. 
Results of the analysis of the effect of interaction between breeding region and groups of lactation on production traits of standard lactations, i.e. means of least squares (LSM), standard errors of means ( $\mathrm{SE}_{\mathrm{LSM}}$ ) and significance of observed effects are presented in Table 3.

Table 3. Means of least squares, standard errors of means and significance of the effect of interaction between farm and groups of lactation on production traits of standard lactations

\begin{tabular}{|c|c|c|c|c|c|c|c|c|c|c|}
\hline \multicolumn{3}{|c|}{ Systematic factors } & \multicolumn{2}{|c|}{$\begin{array}{l}\text { MYSL } \\
(\mathrm{kg})\end{array}$} & \multicolumn{2}{|c|}{$\begin{array}{c}\text { MFCSL } \\
(\%)\end{array}$} & \multicolumn{2}{|c|}{$\begin{array}{l}\text { MFYSL } \\
(\mathrm{kg})\end{array}$} & \multicolumn{2}{|c|}{$\begin{array}{l}\text { 4\%FCMSL } \\
(\mathrm{kg})\end{array}$} \\
\hline Farm & Gr.lac. & $\mathrm{N}$ & LSM & $\mathrm{SE}_{\mathrm{LSM}}$ & LSM & $\mathrm{SE}_{\mathrm{LSM}}$ & LSM & $\mathrm{SE}_{\mathrm{LSM}}$ & LSM & $\mathrm{SE}_{\mathrm{LSM}}$ \\
\hline I & I & 574 & 3941,7 & 31,915 & 3,70 & 0,006 & 144,82 & 1,210 & 3749,0 & 30,757 \\
\hline I & II & 472 & 4384,6 & 35,782 & 3,65 & 0,007 & 159,56 & 1,357 & 4147,2 & 34,484 \\
\hline $\mathrm{I}$ & III & 336 & 4563,3 & 42,249 & 3,65 & 0,008 & 166,13 & 1,602 & 4317,3 & 40,716 \\
\hline $\mathrm{I}$ & IV & 233 & 4548,4 & 50,146 & 3,66 & 0,009 & 166,17 & 1,901 & 4311,9 & 48,326 \\
\hline I & $\mathrm{V}$ & 172 & 4489,0 & 58,154 & 3,66 & 0,011 & 163,91 & 2,205 & 4254,2 & 56,044 \\
\hline $\mathrm{I}$ & VI & 181 & 4203,2 & 56,921 & 3,71 & 0,010 & 155,50 & 2,158 & 4013,7 & 54,856 \\
\hline II & $\mathrm{I}$ & 964 & 3916,1 & 26,285 & 3,81 & 0,005 & 149,20 & 0,996 & 3804,5 & 25,331 \\
\hline II & II & 793 & 4167,7 & 28,559 & 3,80 & 0,005 & 158,18 & 1,083 & 4039,7 & 27,522 \\
\hline II & III & 593 & 4179,5 & 32,534 & 3,79 & 0,006 & 158,03 & 1,233 & 4042,2 & 31,353 \\
\hline II & IV & 402 & 4154,0 & 38,776 & 3,77 & 0,007 & 156,40 & 1,470 & 4007,6 & 37,369 \\
\hline II & $\mathrm{V}$ & 240 & 4044,7 & 49,276 & 3,77 & 0,009 & 152,48 & 1,868 & 3905,2 & 47,488 \\
\hline II & VI & 245 & 3867,5 & 49,082 & 3,78 & 0,009 & 146,09 & 1,861 & 3738,4 & 47,300 \\
\hline III & $\mathrm{I}$ & 1262 & 3313,3 & 23,349 & 3,94 & 0,004 & 130,80 & 0,885 & 3287,3 & 22,501 \\
\hline III & II & 1032 & 3633,3 & 25,211 & 3,93 & 0,005 & 142,69 & 0,956 & 3593,6 & 24,296 \\
\hline III & III & 786 & 3970,1 & 28,574 & 3,91 & 0,005 & 155,18 & 1,083 & 3915,7 & 27,537 \\
\hline III & IV & 578 & 4208,3 & 32,819 & 3,90 & 0,006 & 163,96 & 1,244 & 4142,8 & 31,628 \\
\hline III & $\mathrm{V}$ & 387 & 4338,5 & 39,479 & 3,90 & 0,007 & 169,04 & 1,497 & 4271,0 & 38,046 \\
\hline III & VI & 468 & 4321,1 & 36,825 & 3,90 & 0,007 & 168,52 & 1,396 & 4256,2 & 35,488 \\
\hline \multicolumn{3}{|c|}{$\mathrm{F}_{\text {exp }}$} & \multicolumn{2}{|c|}{$49.41^{* * *}$} & \multicolumn{2}{|c|}{$4.10^{* * *}$} & \multicolumn{2}{|c|}{$49.87^{* * *}$} & \multicolumn{2}{|c|}{$50.14^{* * *}$} \\
\hline
\end{tabular}

N.S. - P $>0.05 ; *-\mathrm{P}<0.05 ; * *-\mathrm{P}<0.01 ; * * *-\mathrm{P}<0.001$;

Significance of the effect of interaction between breeding region and group of lactations on all milk traits of standard lactations was highly significant $(\mathrm{P}<0.001)$, which justified its inclusion into evaluation of breeding value of dairy animals, as confirmed by research of M.M. et al., (1997) and Petrović D.M. et al. (2009).

Share of variance of interaction between breeding region and group of lactations in total variance of production traits of whole lactations was slightly higher and ranged from $0.25 \%$ in milk fat content to $4.12 \%$ in milk fat yield in standard lactations. However, the share of variance in total variability 
unambiguously indicates even more systematic factors and their interactions which influence total variability of observed milk traits of standard lactations, as confirmed by Petrović M.M. et al., (1997) and Petrović D.M. et al. (2009 and 2010).

\section{Conclusion}

Based on presented results the following can be concluded:

- The significance of the effect of interaction between farm and calving season, as well as interaction between farm and group of lactations on all milk traits of standard lactations was very high $(\mathrm{P}<0.001)$, which justifies their inclusion into models for evaluation of breeding value of dairy cows.

- The share of variance of interactions in total variance of milk traits of standard lactations was low, which clearly indicated presence of more systematic factors and their interactions which have influence on total variability of observed milk traits of standard lactations.

\section{Acknowledgment}

This work was financed by the Ministry of Education and Science, Republic of Serbia, projects TR 31086 and TR 31053.

\section{Efekat interakcije sistematskih faktora na mlečnost krava simentalske rase u standardnim laktacijama}

M.D. Petrović, M.M. Petrović, Z. Skalicki, V. Bogdanović, R. Đoković, S. Rakonjac

\section{Rezime}

Uticaj interakcije farme i sezone telenja kao i farme i grupe laktacija na osobine mlečnosti (proizvodnja mleka, mlečne masti, 4\% mast-korigovanog mleka i sadržaj mlečne masti) analizirano je kod 2805 krava simentalske rase sa ukupno 9718 standardnih laktacija koje su bile smeštene na farmi muznih krava "Zlatiborski suvati" na Zlatiboru (578 krava i 1968 laktacija), farmi muznih krava na Poljoprivrednom dobru Dobričevo u Ćupriji (964 krava i 3237 laktacija) i području Kotraže na individualnim gazdinstvima (1263 krava i 4513 laktacija).

Značajnost uticaja interakcija farme i sezone telenja, kao i interakcije farme i grupe laktacija na sve osobine mlečnosti standardnih laktacija bila je vrlo 
visoka $(\mathrm{P}<0.001)$, što opravdava njihovo uključivanje $\mathrm{u}$ modele za ocenu priplodne vrednosti muznih krava.

Udeo varijanse interakcija u ukupnoj varijansi osobina mlečnosti standardnih laktacija bio je nizak (ispod i oko 4\%), što jasno ukazuje na još veliki broj sistematskih faktora i njihovih interakcija koji utiču na ukupnu varijabilnost posmatranih osobina mlečnosti krava u standardnim laktacijama.

\section{References}

BOGDANOVIĆ V., ĐEDOVIĆ RADICA (2003): Testiranje i metode procene priplodne vrednosti simentalskih bikova. Savremeni trendovi u mlekarstvu, Zbornik radova, str. 46-50. Zlatibor.

CHLADEK G., KUCERA J. (2000): Ananalysis of some factors affecting the milk production of cows sired by Montbeliard sires in the Czech Republic. Acta Universitatis Agriculturae et Silviculturae Mendelianae Brunensis. 2000, 48: 5, 21 26; 10 ref.

ĐURĐEVIĆ R. (2001): Genetička analiza mlečnosti i reprodukcijskih svojstava krava simentalske rase. Doktorska disertacija. Poljoprivredni fakultet Novi Sad, 2001.

ĐURĐEVIĆ R., VIDOVIĆ V., ANTOV G., LATINOVIĆ D. (2002): Genetička varijabilnost perzistencije laktacije krava simentalske rase. Biotechnology in Animal Husbandry 18(5-6), p.9-15.

HANSEN L., FREEMAN A.E., BERGER P.J. (1983): Variances, Repeatabilites and Age Adjustmens of Yield and Fertility in Dairy Cattle. Journal of Dairy Science, 66, 281-292.

PANIĆ JOVANKA (2005): Kvantitativno - genetička analiza svojstava mlečnosti krava simentalske rase. Poljoprivredni fakultet, Univerzitet $\mathrm{u}$ Novom Sadu (Magistarska teza).

PERIŠIĆ P. (1998): Reproduktivne i proizvodne osobine različitih genotipova krava simentalske rase. Magistarska teza, Poljoprivredni fakultet, Beograd.

PETROVIĆ D.M., BOGDANOVIĆ V., PETROVIĆ M.M., SNEŽANA BOGOSAVLJEVIĆ-BOŠKOVIĆ (2010): Uticaj paragenetskih faktora na proizvodnju 4\% mast-korigovanog mleka u celim i standardnim laktacijama. XV savetovanje o biotehnologiji. Zbornik radova Vol.15(17), str. 585-590, 2010. Agronomski fakultet, Čačak.

PETROVIĆ D.M., SKALICKI Z., PETROVIĆ M.M., BOGDANOVIĆ V.(2009): The Effect of Systematic Factors on Milk Yield in Simmental Cows Over Complete Lactations. Biotechnology in Animal Husbandry 25(1-2), p 61-71, Belgrade. 
Petrović M.M., Lazarević R., Lazarević LJ., Aleksić S., Miščević B., Perković S. (1997): Proizvodni efekti selekcije aktivne populacije simentalskih goveda u Srbiji. Bootehnologija u stočarstvu, god. 13, Br. 3-4, str. 57-64, Beograd.

PETROVIĆ M.M., SRETENOVIĆ LJILJANA, PANTELIĆ V., ALEKSIĆ S., MIŠČEVIĆ B., BOGDANOVIĆ V., OSTOJIĆ DUŠICA, PETROVIĆ D.M. (2006): Results of the Application of the Technology of Genetic Improvement of Simmental Cattle Population in Serbia. Biotechnology in Animal Husbandry 22(12), p 1-8, Belgrade.

RYCHEN M. (1999): A $6279 \mathrm{~kg}$ milk yield - where are the limits? SchweizerFleckvieh. 1999, No. 7, 26-39.

SONJA JOVANOVAC (1987): Utjecaj sistematskih faktora okoline na mliječnost krava Holstein-Friesian pasmine. Znanost i praksa u poljoprivrednoj i prehrambenoj tehnologiji 17(3-4), 303-314.

STATSOFT INC. STATISTICA FOR WINDOWS, Version 6.0, Computer program manual. Tulsa,: StatSoft Jnc., 1995.

STOJIĆ P., KATIĆ M., LAZAREVIĆ LJ., LATINOVIĆ D., TRIFUNOVIĆ G., RADMILA BESKOROVAJNI, BRKIĆ N. (1995): Ponovljivost dnevnih prinosa mleka tokom laktacije crno belih krava. Prvi Simpozijum za oplemenjivanje organizama sa međunarodnim učešćem. Vrnjačka Banja.

STOJIĆ P. (1996): Faktori korekcije osobina mlečnosti i njihov doprinos oceni priplodne vrednosti bikova i krava. Poljoprivredni fakultet, Univerzitet u Beogradu, Doktorska disertacija. 